\section{Conference announcement}

\section{Conferences 2015-2017}

DOI 10.1515/gps-2014-0081

\section{5}

\section{January 2015}

11-12 January 2015: ICCPE 2015: International Conference on Chemical and Process Engineering Kuala Lumpur, Malaysia

For more information go to http://www.waset.org/ conference/2015/01/kuala-lumpur/ICCPE

13-14 January 2015: ICCEE 2015: International Conference on Chemical and Environmental Engineering Zurich, Switzerland

For more information go to https://www.waset.org/ conference/2015/01/zurich/ICCEE

19-20 January 2015: ICCPE 2015: International Conference on Chemical and Process Engineering London, England

For more information go to http://www.waset.org/ conference/2015/01/london/ICCPE

21-23 January 2015: PACCON 2015 (Pure and Applied Chemistry International Conference)

Bangkok, Thailand

For more information go to http://paccon2015.kmutt.ac.th/

\section{2-23 January 2015: Flow Chemistry India}

Mumbai, India

For more information go to http://selectbiosciences.com/ conferences/index.aspx?conf=FCI15

\section{5-28 January 2015: IFPAC Annual Meeting} Arlington, USA

For more information go to http://www.ifpac.com/

\section{February 2015}

14-17 February 2015: 13th Ibn Sina International Conference on Pure and Applied Heterocyclic Chemistry Hurghada, Egypt

For more information go to http://www.13ibnsina.com/

\section{7-28 February 2015: Flow Chemistry Europe}

Berlin, Germany

For more information go to http://selectbiosciences.com/ conferences/index.aspx?conf=FCE2015

\section{March 2015}

8-14 March 2015: Pittcon 2015

New Orleans, USA

For more information go to http://pittcon.org/

14-15 March 2015: ICCBE 2015: International Conference on Chemical and Biochemical Engineering London, United Kingdom

For more information go to http://www.waset.org/ conference/2015/03/london/ICCBE

\section{April 2015}

16-17 April 2015: ICCEA 2015: International Conference on Chemical Engineering and Applications

Lisbon, Portugal

For more information go to http://www.waset.org/ conference/2015/04/lisbon/ICCEA

26-30 April 2015: AIChE Spring Meeting and 10th Global Congress on Process Safety

Austin, USA

For more information go to http://www.aiche.org/ conferences/aiche-spring-meeting-and-global-congress-onprocess-safety/2015 
27-30 April 2015: International Workshop on Process Intensification 2015 (IWPI 2015)

Samsun, Turkey

For more information go to http://iwpi2015.basari.edu. tr/?callforpapers

\section{May 2015}

10-13 May 2015: 3rd International Conference on Implementation of Microreactor Technology in Biotechnology (IMTB 2015)

Opatija, Croatia

For more information go to http://imtb2015.fkit.hr/

11-12 May 2015: ICCS 2015: International Conference on Chemical Sciences

Montreal, Canada

For more information go to http://www.waset.org/ conference/2015/05/montreal/ICCS

20-22 May 2015: EST - The international conference on Energy, Science \& Technology

Karlsruhe, Germany

For more information go to http://www.est-conference. com/en/home/homepage.jsp

26-28 May 2015: 8th Panhellenic Scientific Chemical Engineering Congress 2015

Thessaloniki, Greece

For more information go to http://www.zapaday.com/ event/208076/2/8th+Panhellenic + Scientific + Chemical $+E$ ngineering+Congress.html

\section{June 2015}

8-10 June 2015: 4th International Conference on Biodiversity \& Sustainable Energy Development Las Vegas, USA For more information go to http://omicsgroup.com/ biodiversity-sustainable-energy-conference-2015/

8-13 June 2015: The 15th International Congress of Quantum Chemistry

Beijing, China

For more information go to http://www.icqc2015.org/dct/ page/1
14-19 June 2015: Gordon Research Conference - High Throughput Chemistry \& Chemical Biology 2015 New London, USA

For more information go to http://www.grc.org/programs. aspx?id=12856

15-16 June 2015: ICCBE 2015: International Conference on Chemical and Biochemical Engineering Toronto, Canada

For more information go to http://www.waset.org/ conference/2015/06/toronto/ICCBE

15-19 June 2015: ACHEMA 2015 - 31st International Exhibition Congress on Chemical Engineering, Environmental Protection and Biotechnology

Frankfurt, Germany

For more information go to http://www.jetro.go.jp/j-messe/ tradefair_en/ACHEMA2015_38622

20-21 June 2015: Gordon Research Seminar Novel Techniques for Synthesizing, Characterizing, and Tracking Engineered Nanomaterials for Sustainable Application of Nanotechnology

West Dover, USA

For more information go to https://www.grc.org/programs.aspx?id=17001

21-24 June 2015: GLS - International Conference on Gas-Liquid and Gas-Liquid-Solid Reactor Engineering New York City, USA

For more information go to http://www.aiche.org/cei/ conferences/international-conference-on-gas-liquid-andgas-liquid-solid-reactor-engineering/2015

21-25 June 2015, 42nd International Symposium on High Performance Liquid Phase Separations and Related Techniques - HPLC 2015

Geneva, Switzerland

For more information go to http://www.hplc2015-geneva. org/

28 June - 2 July 2015: Organometallic Chemistry Directed Towards Organic Synthesis (OMCOS18). IUPAC International Symposium

Sitges-Barcelona, Spain

For more information go to http://www.omcos2015.com/ 


\section{July 2015}

13-14 July 2015: ICCE 2015: International Conference on Chemical Engineering

Stockholm, Sweden

For more information go to http://www.waset.org/ conference/2015/07/stockholm/ICCE

13-15 July 2015: Solid Oxide Electrolysis: Fuels and Feedstocks from Water and Air: Faraday Discussion 182

York, UK

For more information go to http://www.rsc.org/ ConferencesAndEvents/RSCConferences/FD/electrolysisfd2015/

14-16 July 2015: 19th Annual Green Chemistry \& Engineering Conference

Bethesda, USA

For more information go to http://www.gcande.org/

17-18 July 2015: ICCE 2015: International Conference on Chemical Engineering

Oslo, Norway

For more information go to http://www.waset.org/ conference/2015/07/oslo/ICCE

20-23 July 2015: 24th International Symposium: Synthesis in Organic Chemistry

Cambridge, UK

For more information go to http://www.rsc.org/ ConferencesAndEvents/RSCConferences/Organic Synthesis_24/

28 July-2 August 2015: OMCOS 18

Barcelona, Spain

For more information go to: http://www.omcos2015.com/

29-30 July 2015: ICCBE 2015: International Conference on Chemical and Biological Engineering

Istanbul, Turkey

For more information go to http://www.waset.org/ conference/2015/07/istanbul/ICCBE

\section{August 2015}

6-13 August 2015: IUPAC 48th General Assembly Busan, Korea and
9-14 August 2015: IUPAC 2015

Busan, Korea

For more information go to http://www.iupac2015.org/

17-18 August 2015: ICCE 2015: International Conference on Chemical Engineering

Barcelona, Spain

For more information go to http://www.waset.org/ conference/2015/08/barcelona/ICCE

25-27 August 2015: International Congress and Expo on Biofuels \& Bioenergy

Valencia, Spain

For more information go to http://biofuels-bioenergy.conferenceseries.com/

\section{September 2015}

7-9 September 2015: Carbon Dioxide Utilisation: Faraday Discussion

Sheffield, UK

For more information go to http://www.rsc.org/ conferencesandevents/rscconferences/fd/cdu-fd2015/ index.asp?utm_content=chemistry-conferences\&utm source $=$ external-list $\& u t m \_m e d i u m=l i n k \& u t m \_$ campaign=mkt-ape-cdu-fd2015

14-16 September 2015: 2nd International Conference on Past and Present Research Systems of Green Chemistry Florida, USA

For more information go to http://greenchemistry.conferenceseries.com/

17-18 September 2015: ICCEAC 2015: International Conference on Chemical Engineering and Applied Chemistry

Rome, Italy

For more information go to http://www.waset.org/ conference/2015/09/rome/ICCEAC

20-24 September 2015: Instrumental Methods of Analysis-Modern Trends and Applications (IMA) 2015 Kalamata, Greece

For more information go to http://www.ima2015.teikal.gr/

21-24 September 2015: International Conference on Green Energy \& Expo

Seattle, USA

For more information go to http://greenenergy.conferenceseries.com/ 
22-25 September 2015: 15th EuCheMS International Conference on Chemistry and the Environment Leipzig, Germany

For more information go to http://www.icce2015.org/

September 26-0ctober 1st: ECCE10 + ECAB3

Nice, France

For more information go to www.ecce2015.eu

\section{October 2015}

8-9 October 2015: ICCE 2015: International Conference on Chemical Engineering

Bali, Indonesia

For more information go to http://www.waset.org/ conference/2015/07/bali/ICCE

14-15 October 2015: ICCEA 2015: International Conference on Chemical Engineering and Applications

Kuala Lumpur, Malaysia

For more information go to http://www.waset.org/ conference/2015/10/kuala-lumpur/ICCEA

19-21 October 2015: 3rd World Congress on Petrochemistry and Chemical Engineering

Chicago, USA

For more information go to http://omicsgroup.com/ petrochemistry-chemical-engineering-conference-2015/

27-30 October 2015: European Symposium on Chemical Reactor Engineering

Fürstenfeldbruck, Germany

For more information go to http://events.dechema.de/ escre2015

\section{November 2015}

8-12 November 2015: AIChE Annual Meeting

Salt Lake City, USA

For more information go to http://www.aiche.org/ conferences/aiche-annual-meeting/2015

9-10 November 2015: ICCEA 2015: International Conference on Chemical Engineering and Applications

Madrid, Spain

For more information go to http://www.waset.org/ conference/2015/11/madrid/ICCEA
27-28 November 2015: ICCE 2015: International Conference on Chemical Engineering

London, England

For more information go to http://www.waset.org/ conference/2015/11/london/ICCE

\section{December 2015}

30 November-2 December 2015: 2nd International Summit on Past and Present Research Systems of Green Chemistry

New Orleans, USA

For more information go to http://pharmaceuticalconferences.com/green-chemistry-2015/

14-15 December 2015: ICCBE 2015: International Conference on Chemical and Bioprocess Engineering Sydney, Australia

For more information go to http://www.waset.org/ conference/2015/12/sydney/ICCBE

\section{6}

\section{January 2016}

10-16 January 2016: Winter conference on Plasma Spectrochemistry

Tucson, USA

For more information go to http://www.chemistryconferences.com/2016/01/10\%20-\%2016\%20Conference $\% 20$ on $\% 20 \mathrm{Plasma} \% 20$ Spectrochemistry $\% 20$ (Tucson\%20-\%20US).htm

12-13 January 2016: ICCEE 2016: International Conference on Chemical and Environmental Engineering Zurich, Switzerland For more information go to https://www.waset.org/ conference/2016/01/zurich/ICCEE

\section{March 2016}

6-11 March 2016: Pittcon 2016

Atlanta, USA

For more information go to http://pittcon.org/ 


\section{May 2016}

17-20 May 2016: 12th International Workshop on Polymer Reaction Engineering

University of Hamburg, Germany

For more information go to http://events.dechema.de/en/ pre2016.html

\section{July 2016}

3-8 July 2016: ICCC 2016 - 42th International Conference on Coordination Chemistry

Brest, France

For more information go to http://iccc42.ueb.eu/

\section{7}

\section{March 2017}

2-10 March 2017: Pittcon 2017

Chicago, USA

For more information go to http://pittcon.org/

\section{October 2017}

2-6 October 2017: 10th World Congress of Chemical Engineering

Barcelona, Spain

For more information go to http://www.efce.info/index. php?id=112260\&site=efce\&lang=en\&path=1\%2C621 